\title{
Antibiotics Resistance and Biofilm Formation Capacity of Staphylococcus spp. Strains Isolated from Surfaces and Medicotechnical Materials
}

\author{
Akim Socohou, ${ }_{1}^{1}$ Haziz Sina, ${ }^{1}$ Cyriaque Degbey, ${ }^{2}$ Chimène Nanoukon, ${ }^{1}$ \\ Kamirou Chabi-Sika, ${ }^{1}$ Hélène Ahouandjinou, ${ }^{3}$ Halfane Lehmane, ${ }^{1}$ Farid Baba-Moussa, ${ }^{3}$ \\ and Lamine Baba-Moussa ${ }^{1}{ }^{1}$ \\ ${ }^{1}$ Laboratoire de Biologie et de Typage Moléculaire en Microbiologie, Département de Biochimie et de Biologie Cellulaire, \\ Faculté des Sciences et Techniques, Université d'Abomey-Calavi, Cotonou 05 BP 1604, Benin \\ ${ }^{2}$ Institut Régional de Santé Publique de Ouidah, Université d'Abomey-Calavi, Ouidah BP 384, Benin \\ ${ }^{3}$ Laboratoire de Microbiologie et des Technologies Alimentaires, Département de Biologie Végétale, \\ Faculté des Sciences et Techniques, Université d'Abomey-Calavi, Cotonou 01 BP 526, Benin
}

Correspondence should be addressed to Lamine Baba-Moussa; laminesaid@yahoo.fr

Received 19 February 2020; Revised 25 May 2020; Accepted 4 June 2020; Published 27 August 2020

Academic Editor: Joseph Falkinham

Copyright $\odot 2020$ Akim Socohou et al. This is an open access article distributed under the Creative Commons Attribution License, which permits unrestricted use, distribution, and reproduction in any medium, provided the original work is properly cited.

Staphylococcus spp. is most often implicated in nosocomial infections. The objective of this study is to evaluate the susceptibility to antibiotics and the biofilm formation capacity of staphylococci species isolated from surfaces and medicotechnical materials at the university hospital center of Abomey-Calavi/Sô-Ava in Benin. Samples were collected according to ISO/DIS14698-1 standard from the surfaces and medicotechnical materials by the dry swab method. The isolation of Staphylococcus strains was performed on Chapman agar, and their identification was performed using microscopic and biochemical methods. The susceptibility of Staphylococcus isolates to antibiotics was evaluated by the disc diffusion method according to EUCAST and CLSI recommendations. The biofilm formation was qualitatively assessed using microplates. Of the 128 surfaces and medicotechnical material samples analyzed, $77 \%$ were contaminated with Staphylococcus spp. Thirteen species of Staphylococcus were isolated in different proportions but the pediatric department was the most contaminated (33\%) by S. aureus. Resistance to antibiotics considerably varies according to the species of Staphylococcus. However, antibiotics such as chloramphenicol and vancomycin are the most effective on $S$. aureus, whereas coagulase-negative staphylococci developed less resistance to gentamycin and ciprofloxacin. The biofilm test reveals that $37 \%$ of our isolated strains were biofilm formers. Although regular monitoring of hospital hygiene is crucial, the optimal use of antibiotics is a cornerstone of reducing antimicrobial resistance.

\section{Introduction}

The hospital is a place where the risk of infection is very high. These hospital-acquired (nosocomial) infections are recognized as a real public health problem because of their frequency, socioeconomic cost, and severity. Those infections affect patients, their families, and all health professionals. The causes of nosocomial infections are multiple, linked both to care procedures and to behavioral practices. Several studies show that Escherichia coli and Staphylococcus aureus are predominantly isolated from all nosocomial infections [1]. In a study conducted by Ahoyo et al. [2] in the pediatric unit of the Zou and Collines departmental hospital (Benin), $32 \%$ of nosocomial infection involving S. aureus was reported in the care environment.

In fact, staphylococci were identified at the dawn of the Pasteur era and have never ceased to give rise to research, as their importance is so great in pathology. They occupy a significant proportion among the bacteria responsible for serious infections. Moreover, they are observed in multiple 
clinical situations, both in community and nosocomial pathologies [3]. In addition, staphylococci are predominant pathogens of postoperative infections. Among these, coagulase-negative Staphylococcus are the main agents on materials [4]. Some Staphylococcus species can also survive on inanimate surfaces such as bedding, clothing, and door handles [5]. This general tendency to adhere to various surfaces is produced by a polysaccharide matrix called biofilm, and this factor confers significant resistance to antibiotics and to attacks by the immune system $[6,7]$. In hospitals, the selection pressure exerted by antibiotics and antiseptics reinforces the emergence of the most resistant bacteria. Thus, hospital environment appears like multidrug-resistant bacteria reservoirs. This is combined with the many risk factors for cross-transmission of pathogenic germs and can explain their involvement in nosocomial infections [8]. Moreover, mortality linked to infections with multidrug-resistant bacteria remains very high worldwide [9]. Several cases of multidrug-resistant bacteria are reported in Benin [10] and in other sub-Saharan African countries [11].

The predominance of Staphylococcus spp. in hospitals indicates a noncompliance with hygiene rules $[12,13]$. The present study was conducted for a better knowledge of pathogenic Staphylococcus strains for an effective therapeutic approach and a better use of antibiotics. Thus, our study aims at drawing up the resistance profile of Staphylococcus species isolated from the Abomey-Calavi/Sô-Ava university hospital center and determining their capacity to form bacterial biofilm.

\section{Material and Methods}

2.1. Sampling. The samples were collected in the university center hospital of Abomey-Calavi/Sô-Ava (Southern Benin) from January to June 2019 in 5 departments (Neonatology, Pediatrics, Maternity, Operating room, and Central sterilization) according to ISO/DIS14698-1 [14]. For the study, 128 samples were collected by the dry swab method from surfaces and medicotechnical materials such as beds, soils, carriages, baby vanity tables, weighs baby, mattresses, cupboard, and Caesarean boxes. For the sampling, after passing the swabs over defined areas, they were returned to their protective cases. The collected samples were transported using icebox containing coolers $\left(\sim 8^{\circ} \mathrm{C}\right)$ and then $5 \mathrm{ml}$ of Mueller Hinton broth was added to each case and then incubated at $37^{\circ} \mathrm{C}$ for $24 \mathrm{~h}$. Three repetitions were done for each surface and equipment.

2.2. Isolation and Identification of Isolated Strains. The isolation of Staphylococcus bacteria was carried out on Chapman agar. In brief, after 24 hours of incubation, the cases having the cloudy appearance testifying to a bacterial growth were incubated at $37^{\circ} \mathrm{C}$ on Chapman agar for 24 hours [15]. The identification of Staphylococcus strains was carried out using microscopic and biochemical methods (Gram stain, DNase test, and catalase test) and API ${ }^{\circledR}$ Staph (bioMerieux, France).
2.3. Susceptibility of Strains to Antibiotics. The susceptibility of Staphylococcus strain isolated to 15 antibiotics was investigated by the disc diffusion method on the Mueller Hinton agar medium according to the EUCAST [16] and CLSI [17] recommendations. The bacterial suspension was standardized using the $0.5 \mathrm{McF}$ arland control. Fifteen tested antibiotics were penicillin G (P $10 \mu \mathrm{g}$ ), vancomycin (VA $30 \mu \mathrm{g}$ ), fosfomycin (FOS $50 \mu \mathrm{g}$ ), tetracycline (OT $30 \mu \mathrm{g}$ ), amoxiclav (AC $30 \mu \mathrm{g}$ ), cefoxitin (FOX $30 \mu \mathrm{g}$ ), gentamycin ( $\mathrm{G}$ $10 \mu \mathrm{g})$, (C $30 \mu \mathrm{g})$, cephalothin ( $\mathrm{KC} 30 \mu \mathrm{g})$, kanamycin ( $\mathrm{K}$ $30 \mu \mathrm{g}$ ), erythromycin (E $15 \mu \mathrm{g}$ ), ciprofloxacin (CF $5 \mu \mathrm{g}$ ), streptomycin (S $10 \mu \mathrm{g}$ ), trimethoprim (TMP $5 \mu \mathrm{g}$ ), chloramphenicol (C $30 \mu \mathrm{g})$, and ceftriaxone (CI $30 \mu \mathrm{g})$.

2.4. Bacterial Biofilm Formation Test. The bacterial capacity to form biofilm was determined using the method previously described by the Christensen et al. [18]. Therefore, we used in vitro microplate study models to assess qualitatively biofilm formation because of the occurrence of visible film. Thus, from an $18 \mathrm{~h}$ culture in Brain Heart Infusion (BHI) Broth medium, a 48-well microplate was inoculated with $10 \mu \mathrm{l}$ of bacteria suspension to which $150 \mu \mathrm{l}$ of BHI was added. The microplates were incubated for 24 hours at $37^{\circ} \mathrm{C}$ and wells were washed three times with $0.2 \mathrm{ml}$ of sterile physiological water in order to eliminate the free bacteria. The biofilms formed by the adhesion of sessile organisms to the polystyrene support in each of the wells were stained with violet crystal $(0.1 \%)$ for $10 \mathrm{~min}$. The excess dye was then removed by thorough washing with sterile distilled water and the plates were left at room temperature for drying [19]. After air-drying, the occurrence of visible film lined the microplate walls, and the bottom of the walls indicates biofilm production.

2.5. Data Analysis. Data were recorded and analyzed with MS Excel 2013 Spreadsheet. The percentage of resistance was calculated for each antibiotic by dividing the frequency of resistant bacteria by the number of bacteria tested. The Graph Pad Prism 7.00 software was used for the graphs. The threshold of statistical significance was set at $p<0.05$.

\section{Results}

3.1. Identification of Bacteria. Among the 128 samples collected in the study, $77 \%$ were contaminated with Staphylococcus spp., spread in different proportions, into 13 species, namely: S. aureus, S. capitis, S. cohnii ssp. cohnii, S. epidermidis, S. haemolyticus, S. hominis, S. lentus, S. lugdunensis, S. saprophyticus, S. schleiferi, S. sciuri, S. xylosus, and $S$. warneri. Thus, independent of the unit of sample collection, Staphylococcus aureus was the most predominant (43\%) followed by S. xylosus (11\%). S. saprophyticus and S. warneri (1\%) were the least isolated (Figure 1).

The distribution of the major species is very variable depending on the sampling units. It thus appears that the pediatric unit is the most contaminated (33\%) by the strains of S. aureus followed by maternity and neonatology (25\%), 


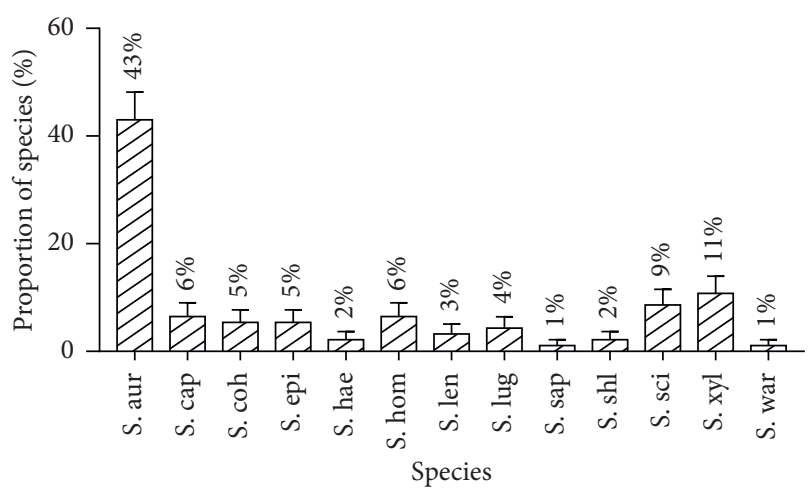

Figure 1: Global distribution of isolated Staphylococcus strains.

and the central sterilization unit is the least contaminated (7\%) (Figure 2).

3.2. Susceptibility to Antibiotics. The isolated strains were split into two categories for the assessment of susceptibility to antibiotics. S. aureus is the coagulase-positive staphylococci (CPS) isolated and the other 12 species (S. capitis, $S$. cohnii ssp. cohnii, S. epidermidis, S. haemolyticus, S. hominis, S. lentus, S. lugdunensis, S. saprophyticus, S. schleiferi, S. sciuri, S. xylosus, and $S$. warneri) are coagulase-negative staphylococci (CNS). Thus, it is observed that all of the $S$. aureus strains are resistant to cephalothin followed by resistance level to fosfomycin (92.5\%) and cefoxitin (87.5\%). The lowest resistance of $S$. aureus was recorded with chloramphenicol (15\%) and vancomycin (25\%).

Considering the coagulase-negative staphylococci, there was recorded high resistance to fosfomycin (94\%) and penicillin (87\%). The lowest resistance in CNS was observed with gentamycin (17\%) and ciprofloxacin (17\%) (Table 1).

3.3. Biofilm Research Test. The biofilm formation test reveals that $37 \%$ of our isolates were biofilm formers. When considering species, we observe that $100 \%$ of the species of $S$. lugdunensis and S. warneri isolated were biofilm-forming bacteria followed by $S$. epidermidis (60\%). However, no biofilm formation was noticed with species such as $S$. cohnii ssp. cohnii, S. haemolyticus, and S. saprophyticus (Figure 3) isolated in our study.

\section{Discussion}

Among the thirteen identified staphylococci species, there was a predominance of Staphylococcus aureus (43\%). A high proportion $(\sim 45 \%)$ of Staphylococcus aureus from hospital environment samples has been reported in Benin [13] and Morocco [20]. However, in Mali, S. epidermidis was reported to be the predominant species in the hospitals [21]. The frequency and the rate of isolated species vary according to their sampling site. Thus, it can be mentioned that species exclusively from human origin (S. capitis, S. hominis, S. lugdunensis, and S. schleiferi), species of both human and animal origin (S. aureus, S. cohnii, S. haemolyticus, $S$. warneri, and $S$. xylosus), and species of animal origin ( $S$.

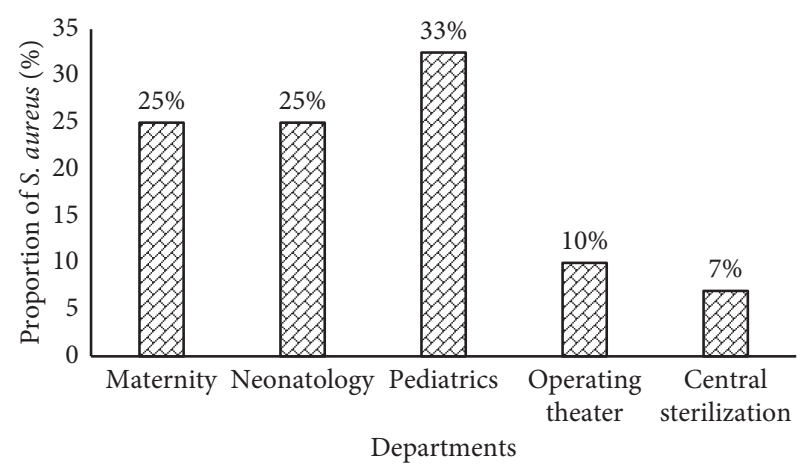

FIGURE 2: Distribution by department of the Staphylococcus aureus strains isolated.

TABle 1: Antibiotic resistance profile of isolated Staphylococcus strains.

\begin{tabular}{lcc}
\hline Antibiotics & $\begin{array}{c}\text { S. aureus resistance rate } \\
(\%)\end{array}$ & $\begin{array}{c}\text { CNS resistance rate } \\
(\%)\end{array}$ \\
\hline Cefoxitin & 87.50 & 66.00 \\
Kanamycin & 80.00 & 42.00 \\
Erythromycin & 75.00 & 54.00 \\
Fosfomycin & 92.50 & 94.00 \\
Vancomycin & 25.00 & 25.00 \\
Cephalothin & 100.00 & 81.00 \\
Trimethoprim & 85.00 & 64.00 \\
Tetracycline & 47.50 & 46.00 \\
Penicillin G & 80.00 & 87.00 \\
Chloramphenicol & 15.00 & 26.00 \\
Streptomycin & 30.00 & 21.00 \\
Amoxiclav & 75.00 & 34.00 \\
Gentamycin & 52.50 & 17.00 \\
Ciprofloxacin & 45.00 & 17.00 \\
Ceftriaxone & 80.00 & 58.00 \\
\hline
\end{tabular}

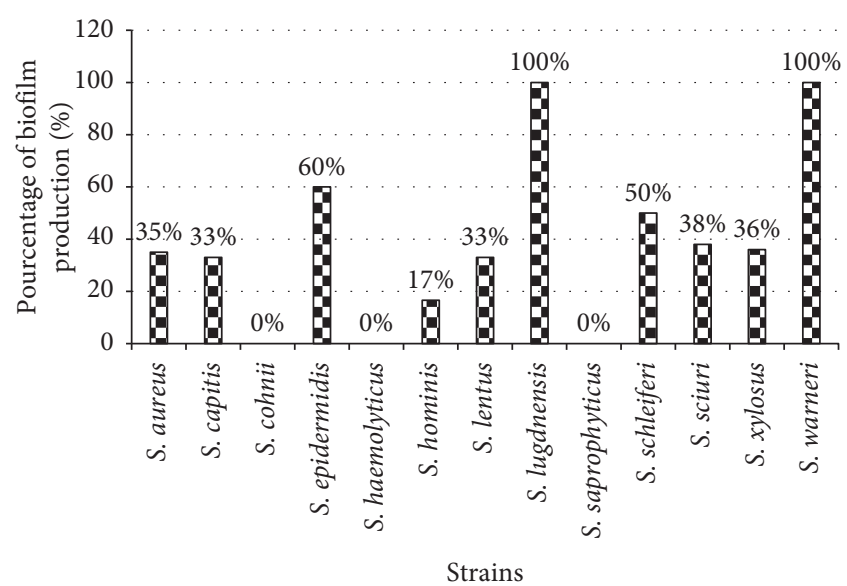

FIgURE 3: Profile of biofilm formation by isolated Staphylococcus strains.

hyicus, S. lentus, and S. sciuri) were observed [21]. The presence of those species (animal and/or human) in the hospital environment is evidence of human contamination and suggests contact between patients and animals or between health personnel and animals in their living 
environment. $S$. aureus is the unique coagulase-positive strain isolated, and its pathogenicity is reported to be related to the expression of several virulence factors [22]. In addition, some CNS such as S. saprophyticus and S. epidermidis through their ability to adhere to the bladder epithelium are able to cause cystitis in young women, and S. lugdunensis is responsible for skin infections and infectious endocarditis [23].

The distribution of species according to the sampling units shows that $S$. aureus isolates are found in all the units. However, pediatrics unit was the most contaminated (33\%) by $S$. aureus. This high presence in these various units is worrying when we know that the deficient immune status of patients represents a breeding ground for its pathogenic microorganisms to trigger an infection. In addition, $30 \%$ of the African strains of $S$. aureus isolated from all types of samples have been shown to produce the LPV toxin $[24,25]$.

In general, hospital bacteria are resistant to several classes of antibiotics. Therefore, beyond the ubiquitous nature of staphylococcal strains, we must add their exceptional ability to develop multidrug resistance to several antibiotics [26]. The $S$. aureus strain isolated in this study showed a high level of resistance to cephalothin followed by fosfomycin and cefoxitin. On the other hand, the relatively low resistance rate of $S$. aureus isolates was observed with chloramphenicol and vancomycin. This resistance to cephalothin recorded suggests that these strains have already been in contact with this generation of cephalosporin. In addition, this confirms the presence of methicillin-resistant $S$. aureus since the cephalothins are only active on sensitive S. aureus. Similarly, resistance rate to fosfomycin and cefoxitin on clinical strains was observed in Brazzaville [27]. Considering fosfomycin, our results are contrary to those obtained in Algeria on clinically isolated $S$. aureus where it was about $90 \%$ of sensitivity [28]. This difference observed between our results may be explained by the intensity of the contact between this antibiotic and the $S$. aureus strains in these two countries. The resistance rate to cefoxitin $(87.5 \%)$ observed in our study is higher than the $43 \%$ obtained on $S$. aureus in the hospital environment at the public hospital center of Boufarik in Algeria [29]. These results suggest that $87.5 \%$ of $S$. aureus obtained in our study is resistant to methicillin (MRSA). Our recorded data are much higher than the rate of MRSA observed in French hospitals, which was from $10 \%$ to $16.5 \%$ in 2016 [30]. Nevertheless, S. aureus showed weak resistance to chloramphenicol (15\%) and vancomycin (25\%). Indeed, a low resistance rate for chloramphenicol $(0.6 \%)$ had been mentioned on community-acquired S. aureus in Morocco [31].

The proportion of resistance to vancomycin is lower than the $63.63 \%$ obtained on clinical strains of S. aureus [27]. However, the efficacy of vancomycin has been demonstrated both on food [32] and clinically isolated S. aureus strains [29]. In addition, Daurel et al. [33] estimated that approximately $90 \%$ of MRSA is hospital-based and that vancomycin may be an alternative for resistance. Therefore, according to observed results, chloramphenicol and vancomycin could be alternative molecules in cases of hospitalacquired MRSA infections. CNS have also high proportions of resistance to fosfomycin and penicillin. Data recorded with fosfomycin are contrary to those published in Algeria [34]. This difference could be explained by a very moderate use of fosfomycin on staphylococcal strains in Algeria. Meanwhile, they reported about $60 \%$ resistance of CNS to penicillin. However, the CNS have shown low resistance to gentamycin and ciprofloxacin. This finding on the low rate of resistance to gentamycin and ciprofloxacin had been observed on clinical CNS isolates in Mali [21]. Given all these results, we believe that an improvement in antibiotic therapy must be taken seriously in these various services.

Many staphylococci have the capacity to produce biofilm, which makes it easier for them to adhere to medical equipment and surface. The biofilm formation test reveals that $37 \%$ of our isolates were biofilm formers. This rate is lower than the $89 \%$ obtained on staphylococcal strains isolated from medical implants in Algeria [35]. Considering species, it is observed that all S. lugdunensis and S. warneri isolated were formative of biofilm followed by $S$. epidermidis (60\%). This proportion of biofilm formation by S. lugdunensis and $S$. warneri is higher than the result obtained by Ahouandjinou [36], which was $28 \%$ and $20 \%$, respectively, for S. lugdunensis and S. warneri on food Staphylococcus spp. strains. This difference could be explained by the low representativeness of these isolates and the origin of collected samples. Our results on S. epidermidis corroborate those of Kara-Terki [37], who revealed that $53.5 \%$ of the strains of $S$. epidermidis isolated from urinary catheters were biofilmforming. However, no biofilm formation was noticed with species such as S. cohnii ssp. cohnii, S. haemolyticus, and $S$. saprophyticus isolated in this study. We can say that isolated S. aureus and biofilm-forming CNS are dangerous germs since their virulence also resides in the capacity to produce an extracellular matrix and constitute a biofilm [38].

It should be remembered that in our study, the influence of biofilm formation on antibiotics resistance was not observed since some strains, although biofilm-forming, were found to be sensitive to certain antibiotics. This could be explained by the fact that we used planktonic colonies to carry out the susceptibility assay. This is why Fitzpatrick et al. [38] consider that antibiotic usually active on bacteria in the planktonic state often proves to be less effective on structures organized in biofilm. Therefore, the eradication of a bacterial biofilm represents a big clinical problem.

\section{Conclusion}

Among the thirteen staphylococcal species identified in the hospital environment, $S$. aureus was the only coagulasepositive staphylococci isolated. These isolates are of various origins, and this implies poor practice of hygienic rules. It is also observed that these identified Staphylococcus strains display variable resistance profiles to tested antibiotics. Antibiotics such as chloramphenicol and vancomycin are more effective on S. aureus. The coagulase-negative Staphylococcus strains developed less resistance to gentamycin and ciprofloxacin. The capacity of staphylococcal cells to form biofilm was high with $S$. lugdunensis, S. warneri, and $S$. epidermidis strains. Among the prevention strategies, the 
optimal use of antibiotics is the cornerstone of the reduction of antibiotic resistance. However, regular monitoring of hospital hygiene is crucial with the use of biodetergents suitable for combating the formation of bacterial biofilms. To end, an evaluation of toxin production by isolated species and a molecular characterization could better inform on their pathogenicity level.

\section{Data Availability}

The data used to support the findings of this study are available from the corresponding author upon request.

\section{Conflicts of Interest}

The authors declare that they have no conflicts of interest.

\section{References}

[1] K. Amazian, J. Rossello, A. Castella et al., "Prevalence of nosocomial infections in 27 hospitals in the Mediterranean region," Eastern Mediterranean Health Journal, vol. 16, no. 10, pp. 1070-1078, 2010.

[2] A.-T. Ahoyo, L. Baba-Moussa, M. Makoutode et al., "Incidence de Staphylococcus aureus résistant à la méticilline dans le service de néonatologie du centre hospitalier départemental du zou et des collines au Bénin," Archives de Pédiatrie, vol. 13, no. 11, pp. 1391-1396, 2006.

[3] K. H. Zahlane, "Staphylocoque: état actuel de l'épidémiologie et de l'antibiorésistance au CHU de Rabat," Maroc Médical, vol. 29, no. 4, pp. 279-285, 2007.

[4] B. Veber, F. Jegou, and D. Jusserand, Département d'Anesthésie-Réanimation, CHU, Charles Nicolle, 1, rue de germont, 76031 rouen cedex: Conférence d'Actualisation, Elsevier, Amsterdam, Netherlands, 2001.

[5] L. Freeman-Cook and K. Freeman-Cook, Staphylococcus aureus Infections, pp. 26-29, Chelsea House Publishers, Philadelphia, PA, USA, 2006.

[6] L. M. Cobb, J. C. Mychaleckyj, D. J. Wozniak, and Y. S. LópezBoado, "Pseudomonas aeruginosa flagellin and alginate elicit very distinct gene expression patterns in airway epithelial cells: implications for cystic fibrosis disease," The Journal of Immunology, vol. 173, no. 9, pp. 5659-5670, 2004.

[7] R. M. Donlan and J. W. Costerton, "Biofilms: survival mechanisms of clinically relevant microorganisms," Clinical Microbiology Reviews, vol. 15, no. 2, pp. 167-193, 2002.

[8] M. Halwani, M. Solaymani-Dodaran, H. Grundmann, C. Coupland, and R. Slack, "Cross-transmission of nosocomial pathogens in an adult intensive care unit: incidence and risk factors," Journal of Hospital Infection, vol. 63, no. 1, pp. 39-46, 2006.

[9] Agence Régionale de Santé Corse, Dossier de Presse Antibioresistance, Agence Régionale de Santé Corse, Ajaccio, France, 2019, http://www.corse.ars.sante.fr.

[10] H. Sina, F. Baba Moussa, T. A. Ahoyo et al., "Antibiotic susceptibility and toxins production of Staphylococcus aureus isolated from clinical samples from Benin," African Journal of Microbiology Research, vol. 5, no. 18, pp. 2797-2803, 2011.

[11] K. O. Akinyémi, O. Oladapo, C. E. Okwara, C. C. Ibe, and K. A. Fsure, "Screening of crude extract of six medecinal plants used in south-west Nigerian unorthodox medecine for antimethicillin resistant $S$. aureus activity," BMC Complementary and Alternative Medicine, vol. 5, pp. 5-6, 2005.
[12] A. Socohou, H. Sina, C. C. Degbey et al., "Risk factors and microbiological control of soils, surfaces and medical-technical equipment at the abomey-calavi/so-ava university hospital center, Benin," International Journal of Pathogen Research, vol. 3, no. 1, pp. 1-9, 2019.

[13] F. C. D. Afle, K. J. M. K. Quenum, S. Hessou, and R. C. Johnson, "État des lieux des infections associées aux soins dans deux hôpitaux publics du sud Benin (afrique de l'ouest): centre hospitalier universitaire de zone d'abomeycalavi/sô-ava et centre hospitalier de zone de cotonou 5," Journal of Applied Biosciences, vol. 121, no. 1, pp. 12192-12201, 2018.

[14] International Organasation for Stadardization (ISO), Cleanrooms and Associated Collected Environnements-Biocontamination Control, International Organasation for Stadardization (ISO), Geneva, Switzerland, First edition, 2003.

[15] M. Cheesbrough, District Laboratory Practice in Tropical Countries: Part 2, pp. 299-329, Cambridge University Press, Cambridge, UK, 2004.

[16] Europeen Commitee on Antimicrobial Susceptibility Testing (EUCAST), Recommandations, Europeen Commitee on Antimicrobial Susceptibility Testing (EUCAST), Växjö, Sweden, 2018.

[17] Clinical and Laboratory Standards Institute (CLSI), Performance Standards for Antimicrobial Susceptibility Testing, Clinical and Laboratory Standards Institute (CLSI), Wayne, PA, USA, 2013, https://www.facm.ucl.ac.be/intranet/CLSI/ CLSI-M100S23-susceptibility-testing-2013-no-protection. pdf.

[18] G. D. Christensen, W. A. Simpson, A. L. Bisno, and E. H. Beachy, "Adherence of biofilm producing strains of Staphylococci epidermidis to smooth surfaces," Infection and Immunity, vol. 37, pp. 318-326, 1982.

[19] S. Stepanovic, D. Vukovic, I. Dakic, B. S. Savic, and M. VabicVlahovic, "A modified microtiter-plate test for quantification of staphylococcal biofilm formation," Journal of Microbiological Methods, vol. 40, no. 2, pp. 175-179, 2000.

[20] S. Madi and K. Djema, Isolement et Caractérisation des Bactéries Multirésistantes Impliquées Dans les Infections Nosocomiales et L'environnement Hospitalier au Niveau de L'hôpital de Lakhdaria, Université Akli Mohand Oulhadj Bouira, Bouira, Algeria, 2019.

[21] M. Fomba, Rôle pathogène et sensibilité aux antibiotiques des acinetobacter et des staphylococcus à coagulase négative à l'hôpital du point g, Ph.D. thesis, Université de Bamako, Bamako, Mali, 2006.

[22] R. J. Gordon and F. D. Lowy, "Pathogenesis of meticillinresistant Staphylococcus aureus infection," Clinical Infectious Diseases, vol. 46, no. 5, pp. 350-359, 2008.

[23] University of Bordeaux, Staphylococcus: Cours de Bactériologie Médecine: Staphylococcus à Coagulase Négative, University of Bordeaux, Bordeaux, France, 2019, http://www. microbes-édu.org/étudiant/Staph.html.

[24] L. Baba Moussa, A. Sanni, A. Y. Dagnra et al., "Approche épidémiologique de l'antibiorésistance et de la production de leucotoxines par les souches de Staphylococcus aureus isolées en afrique de l'ouest," Médecine et Maladies Infectieuses, vol. 29, no. 11, pp. 689-696, 1999.

[25] N. Y. Zinzendorf, L. Baba-Moussa, T. Ouassa et al., "Production de leucotoxines et résistance à la méticilline chez des souches de Staphylococcus aureus isolées à Abidjan," Journal of Science Pharmcology and Biology, vol. 14, no. 1, 2013.

[26] H. K. Allen, J. Donato, H. H. Wang, K. A. Cloud-Hansen, J. Davies, and J. Handelsman, "Call of the wild: antibiotic 
resistance genes in natural environments," Nature Reviews Microbiology, vol. 8, no. 4, pp. 251-259, 2010.

[27] B. T. Ngoulou, G. Ahombo, E. Nguimbi, R. Ampa, and R. Moyen, "Caractérisation moléculaire et distribution des gènes codant la résistance aux macrolides, lincosamides et streptogramines b chez staphylococcus communautaires et cliniques à brazzaville Congo," Afrique Science, vol. 15, no. 5, pp. 352-363, 2019.

[28] S. A. Rebiahi, Caractérisation de souches de Staphylococcus aureus et étude de leur antibioresistance au niveau du centre hospitalo-universitaire de Tlemcen, Ph.D. thesis, Université Tlemcen, Tlemcen, Algeria, 2012.

[29] I. Belal and Z. Chergui, Isolement, Identification de Staphylococcus aureus Résistant à la Meticilline et Étude de Leur Profil de Résistance Aux Antibiotiques, p. 86, Université de Blida, Blida, Algeria, 2019.

[30] N. Brieu and J. Delarbre, "Observatoire national de l'epidémiologie de la résistance bactérienne aux antibiotiques (ONERBA)," ONERBA, Paris, France, Rapport Technique, 2017.

[31] M. Elazhari, K. Zerouali, D. Elhabchi et al., "Sensibilité aux antibiotiques des souches de Staphylococcus aureus communautaires à Casablanca (maroc)," Revue Tunisienne d'Infectiologie, vol. 4, no. 4, pp. 134-140, 2010.

[32] H. Sina, P. Attien, M. Wélé et al., "Sanitary risk factors and microbial contamination of grilled meats sold in cotonou, Benin," Journal of Food Security, vol. 7, no. 5, pp. 175-182, 2019.

[33] C. Daurel and R. Leclercq, "L'antibiogramme de Staphylococcus aureus," Revue Francophone des Laboratoires, vol. 2008, no. 407, pp. 81-90, 2008.

[34] H. S. Afissa, Etude de L'antibiorésistance des Souches de Staphylocoques Isolées à Partir des Dispositifs Médicaux à L'hôpital de Mohamed Boudiaf Ouargla, Université Kasdi Merbah Ouargla, Ouargla, Algeria, 2014.

[35] T. Bali and A. Djebbas, "Résistance aux antibiotiques des staphylocoques formant un biofilm sur les implants médicaux," Université Kasdi Merbah Ouargla, Ouargla, Algeria, 2015.

[36] S. H. S. Ahouandjinou, Qualité microbiologique, antibioresistance des souches de staphylococcus spp et d'Escherichia coli isolées des carcasses bovines au Benin, Ph.D. thesis, Université d'Abomey-Calavi, Cotonou, Benin, 2016.

[37] I. Kara-Terki, Caractérisation et évaluation de la formation de biofilm de souches de staphylocoques isolées de sondes urinaires chez des patients hospitalisés au CHU de Tlemcen, Ph.D. thesis, Université Abou Bekr Blekaid Tlemcen, Tlemcen, Algeria, 2014.

[38] F. Fitzpatrick, H. Humphreys, E. Smyth, C. A. Kennedy, and J. P. O'Gara, "Environmental regulation of biofilm formation in intensive care unit isolates of Staphylococcus epidermidis," Journal of Hospital Infection, vol. 52, no. 3, pp. 212-218, 2002. 